\title{
Can Ageing North Benefit from Expanding Trade with South?
}

\author{
by
}

\author{
Patrick Georges, Katerina Lisenkova, Marcel Mérette
}

\begin{abstract}
In this paper we estimate the benefit for the ageing North countries of diversifying some of its trade away from the other North countries in favour of the South countries. To this end we use a six-region overlapping generations model that takes into account the demographic trends of the $21^{\text {st }}$ century and trade patterns. We show that ageing Northern countries can benefit from "enriching decay" through significant improvement in the terms of trade. We estimate to what extent the enriching decay can be bolstered if the North expands trade with the South. In Europe, for instance, appropriate trade diversification strategy may prop up Europe's real per capita consumption by $3 \%$.
\end{abstract}

\section{Introduction}

According to the World Trade Organization, world merchandise trade and trade in commercial services have expanded between 2005 and 2011 more rapidly in the South than in the North regions. ${ }^{1}$ Consequently the world share of merchandise trade for the North countries like North America and Europe has declined substantially since $1983 .{ }^{2}$ Shirotori and Melina (2009) also report that between 1995 and 2005, South-South trade showed a higher rate of growth than international trade. While developed economies, or the North, remain a significant market for exports from the South, it is South-South trade that shows impressive velocity and growth momentum. Moreover many countries of the

\footnotetext{
${ }^{1}$ According to Table 1.3 of International Trade Statistics 2012 of the WTO, the annual percentage change of trade (exports and imports) during the 2005-2011 period has been well above world average in South and Central America, Commonwealth of Independent States (CIS), Africa, Middle East, and Asia. The percentage change was well below world average in North America and Europe during the same period. ${ }^{2}$ For exports, from $16.8 \%$ to $12.8 \%$ for North America and from $43.5 \%$ to $37.1 \%$ for Europe. For imports, from $18.5 \%$ to $17.1 \%$ for North America and from $44.2 \%$ to $37.1 \%$ for Europe. See Table 1.5 and 1.6 of International Trade Statistics 2012 of the WTO.
} 
South are benefitting from a demographic dividend, which consists of an increasing number of workers and consumers. This combines with better trade-facilitating institutions and infrastructure could make the South a market with major growth opportunities for the North. One may thus wonder whether ageing North countries would benefit from developing further trade links with emerging countries such as China, India, and the Central Asia region.

The objective of this paper is to gauge the benefit for the North countries of diversifying some of its trade away from the other North countries in favour of the South countries taking into consideration the severe ageing population processes in the North. North-South trade agreements are often considered as being more beneficial for "Southern" (developing) countries compared to South-South trade agreements because of current differences in technology and factor abundance. However, this type of argumentation typically neglects several dynamic trends (and adjustments to these trends) such as the demographic changes around the world that accompany the globalization process for goods and services, capital and labour; the large growth differential between the emerging countries and the North resulting from technical progress catch up; domestic debt issues including implicit pension debt that may reduce the prospects of growth, especially in Europe. This paper tries to shed some light on this issue by gauging the economic impact, for the North countries, of some geographical trade diversification away from the North, using a multi-country overlapping generations model that takes into account the demographic trends of the $21^{\text {st }}$ century and trade patterns.

To examine the demographic dimension of trade diversification, we use the model developed by Mérette and Georges (2010) and introduce trade diversification scenarios. 
In this multi-region overlapping generations model, international trade is modelled by assuming that each region produces a single good that is an imperfect substitute for the good produced in any other region. Consequently, households of any region consume a basket of all the goods produced in all the regions of the model. From the baseline scenario that takes into consideration demographic shocks, we estimate the effect of trade diversification by modifying trade shares from their baseline values.

Our model contributes to the existent literature on the concomitant effects of globalisation and population dynamics by both capturing the life cycle feature included in multi-country OLG models and introducing trade in goods between countries. Typically, other models are either trade-oriented (e.g., Dimaranan et al., 2007) and lack the lifecycle assumptions required for a sound analysis of the impacts of population ageing, or multi-country OLG-GE models (e.g., Börsch-Supan et al., 2006; Fehr et al., 2005) that do not truly introduce international trade. The Armington (1969) trade structure that we superimpose on our OLG model implies imperfect substitution between goods of different geographical origins, and market power, so that the law of one price does not hold in the form given by the Heckscher-Ohlin (H-O) model. This assumption, typically used in large scale computable models to generate the observed intra-sectoral trade flows between countries, implies that each country has market power and faces a downwardsloping (foreign) demand curve for its product (i.e., its price elasticity is not infinite). ${ }^{3}$ Compared to the $\mathrm{H}-\mathrm{O}$ model where small shocks can cause production of goods in a country to appear or disappear through comparative advantage adjustment, here quantity adjustment by producers to diverse shocks is somewhat muted by the lack of direct

\footnotetext{
${ }^{3}$ See Lloyd and Zhang (2006) and Zhang (2006) for papers on the effects of the Armington assumption.
} 
competition between regional producers, while terms of trade effects are greater as larger price changes are necessary to clear markets. These features permit us to address the issues of interdependence between trade and growth through terms of trade changes, which is an important focus of Acemoglu and Ventura (2002).

Indeed, Acemoglu and Ventura (2002) show that the absence of clear convergence in incomes per capita and welfare between the North and the South, even in the face of spectacular growth rate in GDP in the emerging countries, might be partly due to a deterioration in the terms of trade as a result of technical catch up that tends to expand the output in the South relative to the North. In the next section, we provide a demographic variant to the Acemoglu and Ventura argument and show that further trade diversification with the North might actually accentuate the impact of terms of trade effects and generate "immizerising growth" and loss of welfare in the South. This suggests that some trade diversification away from the North is not necessarily a bad policy for the North. We argue in fact that an "enriching decay", the symmetric concept of "immiserizing growth", cannot be ruled out for ageing countries (the North) and reflects the possibility that the improvement in the terms of trade of some open-oriented Northern countries might be sufficiently strong that it might outweigh the loss (or part of the loss) due to the lower ability to produce their goods, and sustain consumption per capita in the North.

\section{Population ageing - Any role for trade policy?}

We can find in the literature arguments suggesting different trade strategies for the North countries. For instance, trade diversification towards the South can be 
perceived as an insurance policy for the North exporters against recession times in the North. Clearly this view requires that recessions in the South are unsynchronized with those in the North - if all markets are subject to the same business cycles, then, there may be little scope for diversification. Other economists (OECD, 2006; UNCTAD, 2004) suggest that South-South trade offer wide scope for specialization and efficiency gains as barriers to South-South trade are higher than those governing South trade with the North, and distance-related cost are higher.

There is also a large literature that combines growth and trade into models of North-South interaction. A long standing issue raised in this literature is that given that one of the North-South asymmetries is that the North leads in technical progress, how does the South adjust to such changes? And do asymmetries mean that standard prescriptions on the mutual benefits of free trade and free movements of capital need to be modified? The answer to this question is not unambiguous and depends on the model used, and there are basically four such generic models (Findlay, 1980; Ben-David and Loewy, 2000; Krugman, 1979; Grossman and Helpman, 1991).

Finally, whenever a large country expands the supply of one of its products it depresses the product's price on world markets. As a result, the value of output declines, magnifying the effect of diminishing returns to accumulation. The importance of this effect was studied by Acemoglu and Ventura (2002) and this is the argument we explore further in this section in the context of significant world demographic changes.

We argue, in fact, that although population ageing in the North is expected to have a negative impact on GDP, international trade should prop up real consumption per capita through terms of trade improvements during the first half of the $21^{\text {st }}$ century. This reflects 
a population ageing gap between the North and its South partners with 'younger' populations whose demographic projections entail relatively smaller negative supply shocks and lesser relative price increases. However, the gains resulting from the globalization of trade flows might be intensified through a strategic pattern of NorthSouth trade diversification that takes into account the extent and timing of population ageing in diverse regions of the world. The main policy implication of this analysis is that a North-North trade diversification scheme is not necessarily desirable. In fact, both forces of demographics and technical catch up reinforce themselves to lead to this conclusion. However, unlike demographics, the catch up process and long term growth of the South countries is not a new argument in favour of trade diversification. ${ }^{4}$ Hence, here, we focus on the demographic transition as the only factor of investigation in order to establish the case for trade diversification and North-South Free Trade Agreements (FTAs).

A typical framework (see for example Foot 2007) that is used to organize discussions on the channels of transmission of population ageing on GDP is the decomposition of GDP per capita into 5 terms - productivity, effort, employment rate, labour force participation, and the ratio of adult to total population:

$$
\frac{\mathrm{Q}}{\mathrm{POP}}=\underbrace{\frac{\mathrm{Q}}{\text { Hours }}}_{\text {Productivity }} \times \underbrace{\frac{\text { Hours }}{\text { Employed }}}_{\text {Effort }} \times \underbrace{\frac{\text { Employed }}{\text { Labor Force }}}_{\text {Employment Rate }} \times \underbrace{\frac{\text { Labor Force }}{\text { Age 15+ }}}_{\begin{array}{c}
\text { Labor Force } \\
\text { Participation }
\end{array}} \times \underbrace{\frac{\text { Age 15+ }}{\text { POP }}}_{\begin{array}{c}
\text { Adult over } \\
\text { Total Population. }
\end{array}} .
$$

The literature generally suggests that population ageing might tend to reduce the first four ratios if older workers are less productive, if they chose to work less hours, if

\footnotetext{
${ }^{4}$ See for example Romer (1990), Grossman and Helpman (1990), Rivera-Batiz and Romer (1991), RiveraBatiz and Xie (1993). For a relatively recent survey, see López (2005).
} 
there is discrimination against older workers (ageism) on the job market resulting in a lower employment rate or incentives to retire and exit the labour force. Major policy reforms aimed at mitigating the impact of population ageing also follow from this decomposition and include policies focusing on increasing productivity and effort, employment policies including policies that discourage ageism, and policies targeting labour force participation by delaying the normal age of retirement or by favouring higher immigration (see for example Banerjee and Robson, 2009). This framework, however, obscures any direct role for trade policy, or suggests, at best, an indirect link if we are willing to accept that international trade tends to enhance productivity and growth. ${ }^{5}$ On the other hand, a more direct role for trade and trade policy may be suggested if we look at the ratio of real consumption per capita, and its relation to GDP per capita:

$$
\frac{C}{P O P}=\frac{P_{Q}}{P_{C O N}} \times\left\{\frac{Q}{P O P}-\frac{\text { Saving }}{P O P}\right\}
$$

Real consumption is defined as real disposable income minus real private saving. The basis for calculating real income is of course real production $Q$, while the nominal value of this income is $P_{Q} \times Q$ where $P_{Q}$ is the price of the domestically produced good. To get the real spending value of this income, we divide by the average price of the goods purchased by domestic residents, $P_{C O N}$. This consumer price is defined as an average of the price of the domestically produced good and the foreign produced goods with weights given by the average propensity to spend on the domestically produced good and the

\footnotetext{
${ }^{5}$ By only focusing on GDP per capita this framework also obscures many other dimensions of the economic and fiscal consequences of ageing such as the impacts on sectors (e.g., sectoral shifts in demand and thus in job opportunities in all major occupational groups-see Guest, 2007; Fougère et al., 2009; Lürhrmann, 2005), on factor markets and remunerations (e.g., relative scarcity of labour versus capital-see Cutler et al., 1990; Poterba, 2001), and on the social security systems and reforms (e.g., placing more of the pension responsibility on individuals by converting to defined-contribution approaches-see De Nardi et al., 1999).
} 
imported good. In a closed economy, $P_{Q}=P_{C O N}$ when taxes are ignored. This is not true for an open economy, and this relative price ratio may be viewed as the terms of trade.

Variations in the terms of trade have led to famous debates, including Bhagwati (1958) and the Laursen-Metzler (1950). According to Laursen-Metzler (1950) argument, any terms of trade improvement per se (here, a relative increase in $P_{Q} / P_{C O N}$ ) might have different effects on real consumption depending on whether the effect is perceived as transitory or permanent. If the improvement is transitory, then real consumption could remain constant while saving would increase (see equation above), which would eventually affect the current account of the country (the Laursen-Metzler effect). In case of a permanent improvement in the terms of trade, however, real consumption would increase - the "reverse" Laursen-Metzler effect as identified by Obstfeld (1982). Population ageing is a structural shock involving the possibility of long-lasting changes in the terms of trade so that most of its effect should be reflected in real consumption rather than in saving. From a perspective of currently living generations this shock will be perceived as permanent. We must also expect a transfer of resources from the working-age population to the retirees, which would likely increase aggregate consumption further. Second, we argue that an "enriching decay", the symmetric concept of Bhagwati (1958)'s “immiserizing growth”, cannot be ruled out for developed ageing countries (the North). ${ }^{6}$ This reflects the possibility that the improvement in the terms of trade (a relative increase in $P_{Q} / P_{C O N}$ ) of some free trade oriented North countries might

\footnotetext{
${ }^{6}$ Bhagwati (1958) concept of "immiserizing growth" is the possibility of a decline in a country's wellbeing in response to its own ability to produce more of its export good. By expanding its ability to produce this good the country increases its supply of exports. This drives down the relative price of this good in the world markets, or increases the relative price that it must pay for its import, which lowers well-being. The "immiserizing growth" scenario reflects the possibility that the decline in the country's terms of trade is so bad that it outweighs the benefit of the extra ability to produce.
} 
be sufficiently strong that it might outweigh the loss (or part of the loss) due to the lower ability to produce their goods, and sustain consumption per capita in the North (in terms of equation above, the increase in the price ratio might offset (partly or totally) the fall in real output per capita resulting from population ageing).

As a matter of fact, this point is a demographic variant of the Açemoglu and Ventura (2002) argument. They try to explain why the world income distribution had been relatively stable since the 1960 (no convergence), despite the spectacular growth rates of some developing countries. Their argumentation is that growing (developing) countries suffer from deteriorating terms of trade so that their trading partners enjoy improving terms of trade. As a result, a growing country confers benefits on its trade partners and the benefits of growth are diffused throughout the world via terms of trade adjustments. Our parallel point here is that developed North countries might not suffer as much as typically expected from population ageing because the cost of population ageing in terms of slower growth (or decline) can also be diffused throughout the world via terms of trade adjustments. This also implies that younger countries may not fully benefit from their advantageous demographic projections because they could suffer from a terms of trade deterioration.

Trade policy may then play a role in the population ageing debate insofar as it might affect the magnitude of the terms of trade change. Clearly a relatively closed economy could not suffer or benefit from the terms of trade changes. But an open economy with some market power could possibly mitigate the impact of ageing by selecting younger (and fast growing) trade partners, which could result in downward pressures in the consumer prices (as consumers and firms would buy more from countries 
whose producer prices fall in relative terms) and thus an increase in its terms of trade. Therefore, from the perspective of older North countries, the gains resulting from the globalization of trade flows might be intensified through a strategic pattern of NorthSouth trade diversification that takes into account the extent and timing of population ageing in diverse regions of the world. This argument may lead older developed North countries (such as Europe) to sign free trade agreements with younger developing countries. We explore this argument using a multi-country overlapping generation computable general equilibrium model.

\section{The model}

The model economy is made up of six regions: North-America is the aggregation of the US and Canada. Europe is aggregated into one region (EU-15). Asia is disaggregated into three countries: Japan, as it represents a developed country at the advanced stage of population ageing, and China and India as they are emerging countries with very different demographic prospects ${ }^{7}$. Remaining countries are aggregated into one region - the Rest of the World (ROW), to close the model. This section briefly describes the production sector in an unspecified region, the household sector and pension plans, the government sector, and the market equilibrium conditions. We complete the section with a brief discussion of the calibration and the demographic projections of the regions of the model. Model equations referred to in the text are presented in Appendix. Table A1 contains model variables and parameters.

\footnotetext{
${ }^{7}$ On January $18^{\text {th }}$ 2013, the National Bureau of Statistics of China announced that the number of Chinese aged 15 to 59 declined (by a total of 3.45 millions) for the first time in 2012 .
} 


\subsection{Production sector}

In each region $j$, a representative firm produces at time $t$ a single good using a Cobb-Douglas technology (eq.1). The firm hires effective units of labour and rents physical capital. Both factors are region-specific. Firms are perfectly competitive and factor demands (eq.2 and 3) follow from profit maximization.

\subsection{Household behaviour and pension plans}

At any given time, and in each region, the household sector is represented by seven overlapping generations of adults. In each period, the oldest generation dies and a new young generation takes its place. Individuals are assumed fully dependent on their parents and play no active role in the model until the age of 15 . Then they enter the labour force, retire (on average) at age 65 and die at the end of their $84^{\text {th }}$ year. All individuals within 10-year age cohorts $g g$ (i.e., 15-24, 25-34, ..75-84 age groups) are assumed identical. Therefore the model portrays seven representative individuals that characterise the behaviour of the seven cohorts. These individuals are assumed to be forward-looking, to have perfect foresight, and to behave in a manner that maximises their lifetime utility. Each period in the model effectively corresponds to 10 years.

An individual who begins economic life in region $j$ at time $t$ chooses a profile of consumption over the life cycle, in order to maximize a CES type inter-temporal utility function (eq.4). The dynamic budget constraint (eq.5) is standard. The household does not leave bequests to its children in this simple framework. 
Labour income is defined by eq. 6 where a distinction is made between exogenous supply of physical units of labour $(L S)$ and effective labour supply, which takes into account the individual's age-dependent productivity (earnings) profile $\left(E P_{j, g g}\right)$. Productivity profile is defined as a quadratic function of age (eq.7) with parametric values chosen to ensure that its maximum is reached between mid-life and retirement. Differentiating utility function under the life-time budget constraint yields the first-order condition for consumption (eq.8).

Trade in goods is introduced in the model by assuming that each region produces one single good which is an imperfect substitute to the good produced in any other regions (the Armington assumption). Therefore, in the intra-temporal optimization households allocate consumption expenditures across the seven imperfectly substitutable regional final goods using CES function. Eq.9 gives the consumption demand by household $g g$ of region $j$ for a region $i$ good. The composite consumption price index is consistently defined as a non-linear weighted average of regional prices (eq.10).

Retirees' pension benefits are proportional to their lifetime labour earnings (eq.11) and the fraction is defined by an exogenous pension replacement rate. Pension benefits are financed by contribution rates on labour income (eq.12) where $g j$ and $g m$ are the (five) working-age and (two) retired generations, and where CTR is the endogenous region-specific contribution rate needed to finance the defined-benefit pensions of the pay-as-you-go (PAYG) plan. The population size of working-age and retired cohorts, $\operatorname{Pop}_{j, t, g i}$ and $P o p_{j, t, g m}$ in eq.12 is exogenously given by demographic laws of motion (eq.29) discussed below. 


\subsection{Saving instruments, asset returns and investment}

Household saving can be "invested" in government bonds (issued to finance public debt) and capital shares (issued to finance physical capital formation). Physical capital formation is based on an investment technology characterized by a CES function that combines goods from the seven regions in order to build an aggregate investment good (eq.13) whose composite price index is given by eq.14. The accumulation of each region's capital stock is given by the usual law of motion subject to depreciation (eq.15). In this model we assume perfect substitution between domestic assets (physical assets and governments bonds), and perfect financial capital mobility across countries. Perfect substitution implies that the expected (ex ante) rate of return on physical capital and renting it to firms must be equal to the expected rate of return on government bonds (eq.18). The ex ante rate of return on physical capital (purchased at time $t-1$ and rented to firms throughout period $t$ ) is the real rental price of capital (expressed in terms of the price of the investment good) plus the expected capital gains, net of depreciation cost (eq.16). The ex ante rate of return on government bonds (issued at end of $t-1$ and held throughout period $t$ ) is the promised rate of return on a zero-coupon bond plus its expected capital gains due to changes in bond prices (eq.17). Perfect financial capital mobility across countries implies that the expected rate of returns on government bonds of all countries will be equalised ex ante leading to a unique world interest rate (eq.19). Finally, eq.20 follows because physical capital has the same ex ante return as financial capital. 


\subsection{Government sector}

The government budget constraint is standard and given by eq. 21 with a budget balance including government spending, debt servicing (plus the refinancing of the entire stock of one-period debt at current bond prices) and tax revenues from different sources. The model assumes that real government program spending per capita remains constant over time. Thus, population changes imply adjustments in real program spending measures (Gov), and governments issue bonds (and therefore let their public debt adjust (left hand side of eq.21)) to finance their overall budget balances. However, the model imposes the condition that governments target a constant debt-to-GDP ratio, which requires that labour tax rates must also adjust every period. Other tax rates (on capital and consumption) remain constant. The government purchases goods from all regions $i$ according to eq.22 and the composite government good price index is consistently defined as a non-linear weighted average of regional prices (eq.23).

\subsection{Market and aggregation conditions}

The model assumes that all markets are perfectly competitive. The equilibrium condition for the goods market is that each regional output must be equal to total demand originating from all regions $i$ (eq.24). Labour and physical capital are immobile across regions and a market exists for these two factors in each region (eq.25 and 26). The world capital market must be in equilibrium, that is, the world stock of wealth (Lend) accumulated at the end of period $t$ must be equal to the value of the world stock of government bonds and stock of physical capital at the end of $t$ (eq.27). The current account of region $j$ can be derived from this model as the difference between national 
saving (private saving of all generations and public saving) and domestic investment (eq. 28) $)^{8}$.

\subsection{Calibration}

The wage income tax rates, capital income tax rates and consumption tax rates for North America, Europe and Japan are directly based on Carey and Rabesona (2002), while the pension benefit rates are taken from OECD (2005) - see Table 1. However, for China, India and ROW, it is extremely difficult to set these rates with precision since there is little reliable data available. In this paper, we assume lower pension benefit rates for them compared to the developed regions. Considering that the tax collecting system and social security programs of India may not be as advanced as in developed regions, we have set relatively lower tax rates and pension benefit rate compared to other regions. Correspondingly, it is also reasonable to set moderate tax rates for ROW. Moreover, because of the heavy presence of state-owned enterprises in China's economic structure, its wage and capital income tax rates are assumed to be relatively higher compared to other economies in order to incorporate the crowding out effects. Meanwhile, the consumption tax rate of China is set to be lower to ensure that its overall tax levels are consistent with other regions. According to the definition of economically active population, we assume workers retire at age 65 with the exception of workers in Europe and Japan who are assumed to retire at age 60 and 70 respectively, reflecting their

\footnotetext{
${ }^{8}$ Alternatively, the current account is either given as the trade balance plus the interest revenues from net foreign asset holdings (eq.28'), or as the difference between nominal GNP (GDP including interest revenues on net foreign assets) and domestic absorption. All three alternative formulations have been coded as an internal check.
} 
different working culture. The intertemporal elasticity of substitution $(1 / \gamma)$ is set to 1.5 for all countries, which is in the standard range of $1-4$. The (10-year) rate of time preference is solved endogenously in the calibration procedure in order to generate realistic country specific consumption profiles and capital ownership profiles per age group for which no data are easily available. ${ }^{9}$ A higher rate of time preference reflects a bias towards current versus future consumption and the values generated endogenously are consistent with the priors that, say, Indians are more patient than Americans or Japanese. Finally, the remaining parameters in the model are calibrated on the GTAP-6 database (Dimaranan and McDougall, 2005). This also includes the Armington elasticity of substitution between goods of different countries, which is set uniformly equal to 2.5 across countries for private consumption, investment and government consumption.

\section{Table 1 Calibration parameters}

\begin{tabular}{lllllll}
\hline Country/Region & NAM & EUR & JPN & CHN & IND & ROW \\
\hline Intertemporal elast. of substitution, $1 / \gamma_{j}$ & 1.5 & 1.5 & 1.5 & 1.5 & 1.5 & 1.5 \\
Armington trade elasticity, Sig ${ }_{j}$ & 2.5 & 2.5 & 2.5 & 2.5 & 2.5 & 2.5 \\
Rate of time preference $\left(10-\right.$ year), $\psi_{j}$ & 0.28 & 0.27 & 0.28 & 0.25 & 0.21 & 0.17 \\
Wage income tax rate, $\tau^{L}{ }_{j, t}$ & 0.234 & 0.38 & 0.241 & 0.45 & 0.20 & 0.26 \\
Capital income tax rate, $\tau^{K}{ }_{j, t}$ & 0.273 & 0.287 & 0.279 & 0.50 & 0.25 & 0.30 \\
Consumption tax rate, $\tau^{C}{ }_{j, t}$ & 0.064 & 0.178 & 0.064 & 0.05 & 0.15 & 0.15 \\
Effective retirement age & 65 & 60 & 70 & 65 & 65 & 65 \\
Pension benefit rate, PensR $_{j, t, g g}$ & 0.386 & 0.536 & 0.503 & 0.30 & 0.20 & 0.35 \\
\hline
\end{tabular}

\footnotetext{
${ }^{9}$ The rate of time preference and the intertemporal elasticity of substitution determine together the slope of the consumption profiles across age groups in the calibration of the model (where population is assumed stable) and this is also the slope of the consumption profile of an individual across his lifetime in the simulated model in absence of demographic shocks.
} 


\subsection{Demography and United Nations population projections}

Detailed demographic projections of the UN are the exogenous forcing process of our OLG simulation model. We calibrate model population structure in order to simulate a baseline OADR (defined here as population aged $65+$ divided by working age population (15-64)) consistent with the UN medium variant demographic projections available for the period 1950-2100 (United Nations Population Division, 2011).

\section{Figure 1. Old-age dependency ratio}

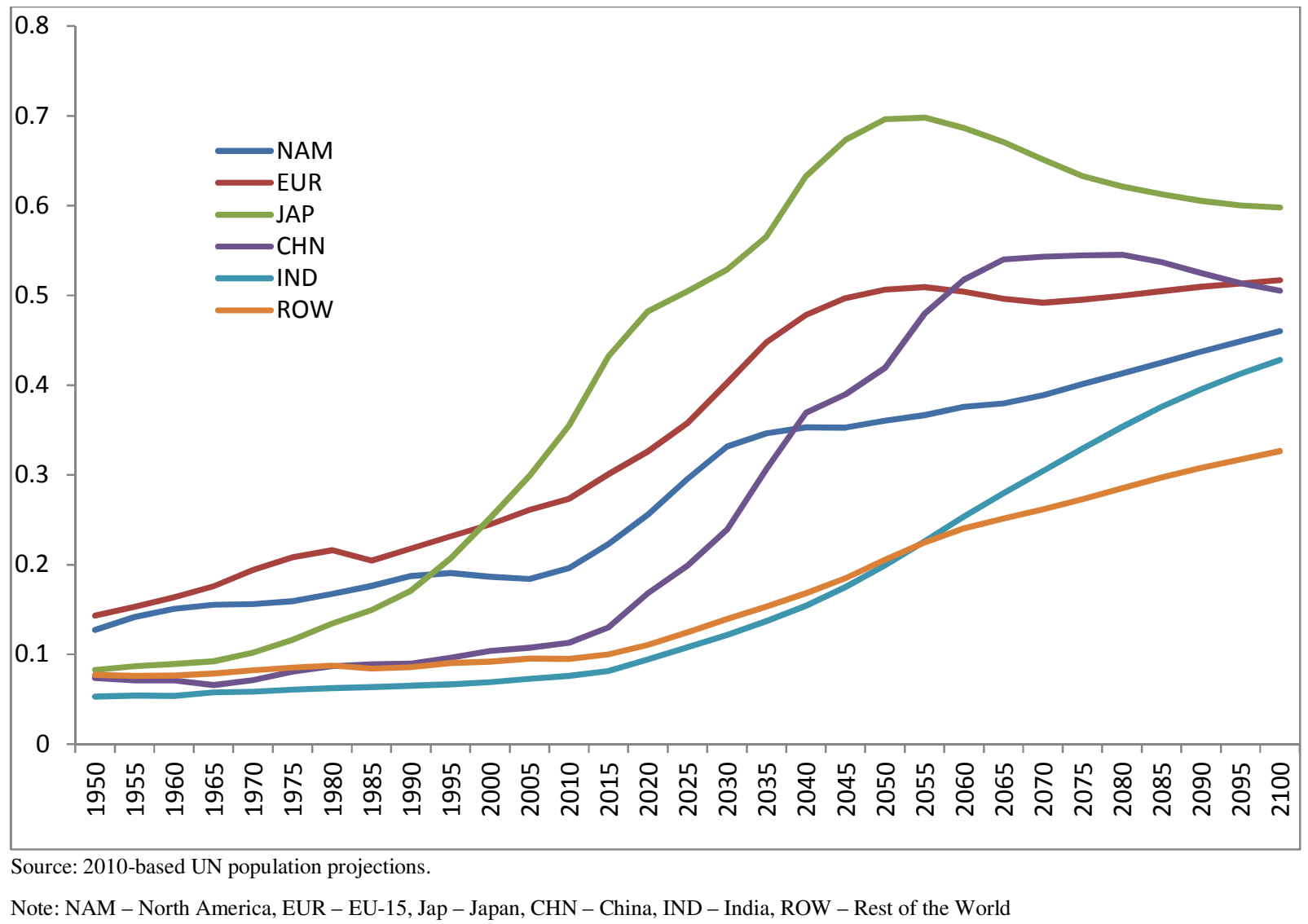


Figure 1 presents OADR. It illustrates that while demographic changes are occurring in all regions of the world, the extent and timing differ substantially across countries. Japan is the oldest country in the world and according to the UN population projections it will reach the highest level of OADR. Europe and North America are also ageing fast with Europe having consistently higher OADR compared with North America. But the most interesting transition is that of China. It was a very young country at the turn of the $21^{\text {st }}$ century and had OADR very close of that of India and the ROW. However one child policy will result in remarkably fast pace of ageing and by 2060 it will have OADR higher that in Europe.

\section{Simulation Results}

In this section, we report our simulations results. We start by discussing briefly the outcomes of the baseline demographic shock ${ }^{10}$ and follow with the discussion of the results from trade diversification scenarios. All the results are presented relative to benchmark without population ageing.

\subsection{Population ageing: Demographic projections and simulation results}

Figure 2 demonstrates that as a result of population ageing the North countries experience significant decline in real GDP per capita during the simulation period North America by 5\%, Europe by over $10 \%$ and Japan by almost $15 \%$. India and ROW experience growth in real GDP per capita as their demographic situation is much more

\footnotetext{
${ }^{10}$ This analysis is provided with more details in a similar model in Mérette and Georges (2010).
} 
beneficial, although in ROW there is a small decline after 2050. China again stands out among the South countries. As we saw on Figure 1 it is projected to have the highest speed of population ageing and it results in the fastest decline in real GDP per capita - by the end of the simulation period it declines by almost $20 \%$.

Figure 2. Changes in real GDP per capita, baseline scenario

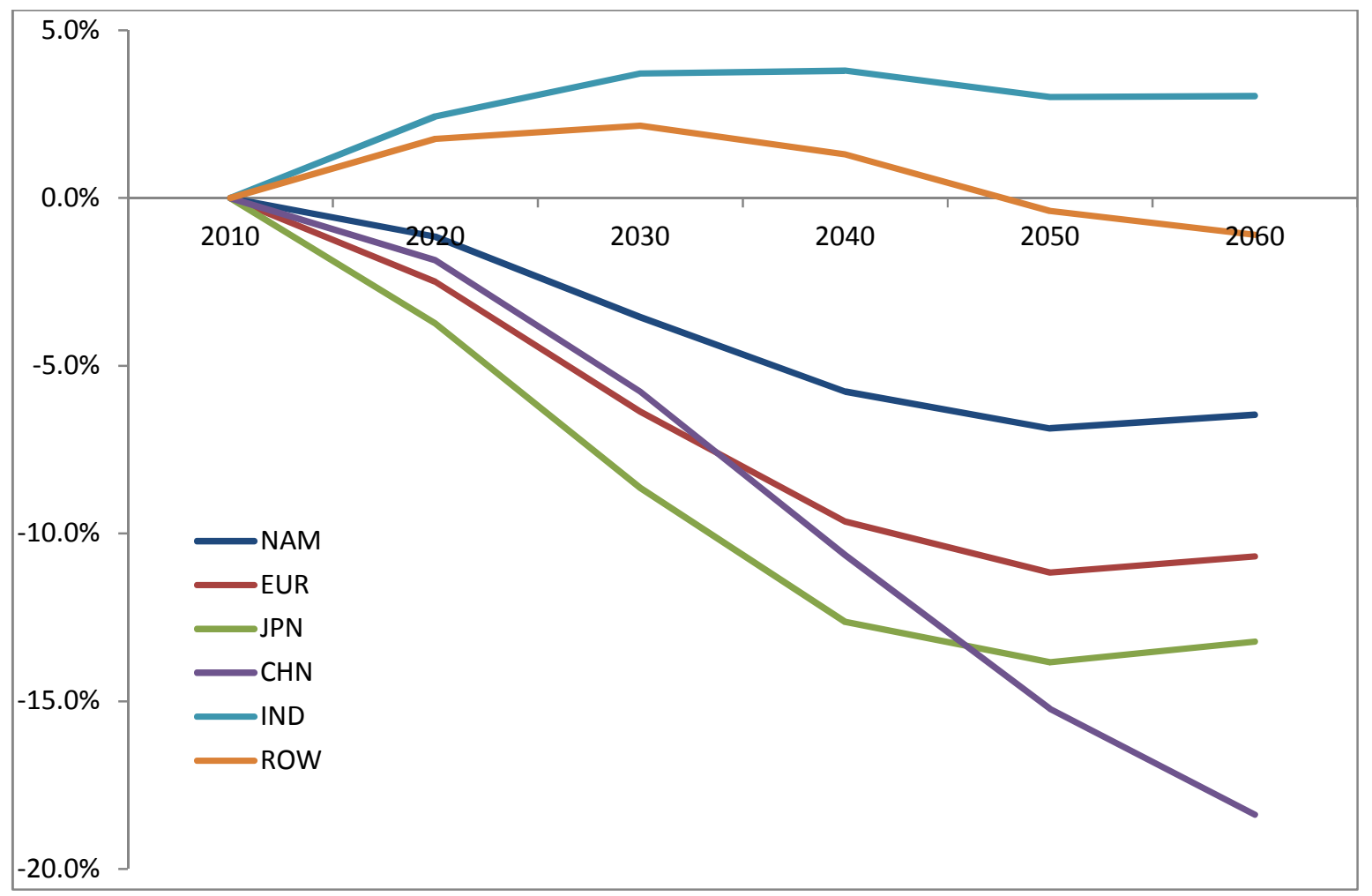

Figure 3 presents changes in real consumption per capita. Here the situation is better compared with the real GDP per capita. All countries have better results. For example, by 2060 North American consumption per capita declines by only $1.3 \%$, while GDP per capita declines by $6.5 \%$. Europe experiences improvement in real consumption 
per capita of over 5\%. India and ROW also have large growth in real consumption per capita of around $20 \%$ and over $15 \%$ respectively. The reasons for this are twofold. First of all, the North countries are benefiting from improvements in terms of trade because their domestic good's price increases relative to their import's price (see Table 2). At the same time the South countries are benefiting because of significant improvement in their capital to labour ratios and growing labour incomes associated with this.

Figure 3. Changes in real consumption per capita, baseline scenario

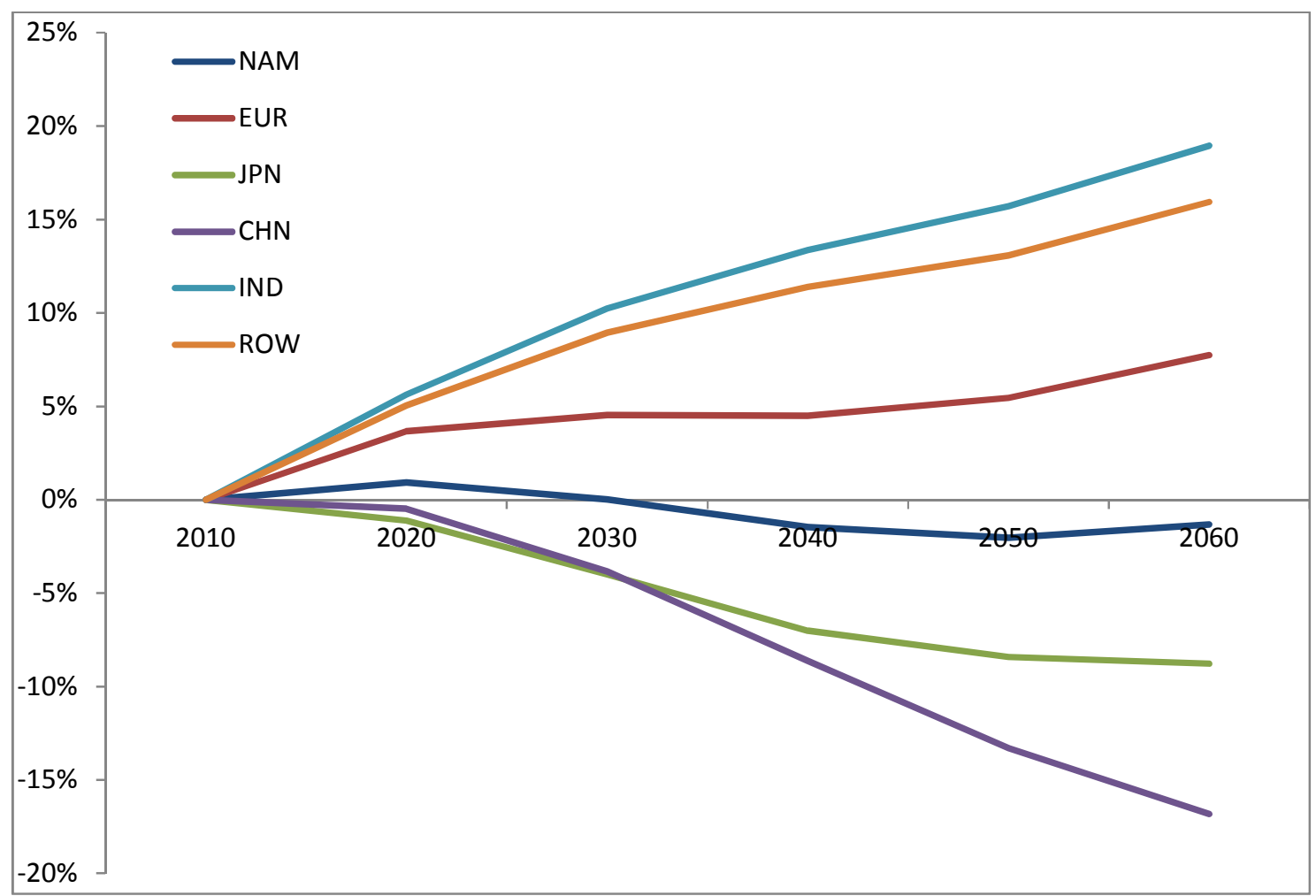


Table 2. Terms of trade (approximated by $\boldsymbol{P}_{Q} / \boldsymbol{P}_{C O N}$ )

\begin{tabular}{c|cccccc} 
& 2010 & 2020 & 2030 & 2040 & 2050 & 2060 \\
\hline NAM & 1.01 & 1.01 & 1.02 & 1.02 & 1.02 & 1.02 \\
EUR & 1.04 & 1.05 & 1.06 & 1.07 & 1.08 & 1.09 \\
JPN & 1.03 & 1.03 & 1.04 & 1.05 & 1.06 & 1.07 \\
CHN & 0.99 & 1.00 & 1.00 & 1.00 & 1.01 & 1.01 \\
IND & 0.99 & 0.99 & 0.98 & 0.98 & 0.98 & 0.98 \\
ROW & 0.97 & 0.96 & 0.96 & 0.96 & 0.95 & 0.95
\end{tabular}

\subsection{Trade diversification}

The demographic simulations described above assume that the North region pursues no explicit policies to diversify trade. However, by examining alternative scenarios in which trade shares are modified from their baseline values, we can estimate the effect of trade diversification on real consumption per capita for North and South regions. In the following simulations, we assume that the North region succeed in changing its import shares following trade initiatives such as multilateral trade promotions, formal preferential trade agreements with selected countries, ad hoc promotion or a unilateral decision to reduce or eliminate trade barriers. We report here two opposite scenarios.

In Scenario 1, we assume that the North countries increase their trade intensity with other North countries at the detriment of the South countries. More precisely, we assume that the North increases its import shares from other North countries by $5 \%$ and reduce equivalently its import shares from the South region. From a modelling perspective the shock is implemented in 2020 by exogenously changing the share parameters in the Armington-based import demand functions. The 5\% share increase is spread proportionally between the North countries and the 5\% share decline is spread 
proportionally between the South countries. The change in the trade share of North imports is considered modest given the recent evolution of international trade. Table 3 reports the benchmark and the counterfactual import shares of Scenario 1.

\section{Table 3. Benchmark and Counterfactual Regions' Import shares ${ }^{11}$}

\begin{tabular}{lccc}
\hline & NAM & EUR & JPN \\
\hline NAM & & $29.4 \%(25.5 \%)$ & $22.6 \%(20.1 \%)$ \\
EUR & $31.9 \%(28.4 \%)$ & & $22.5 \%(20.0 \%)$ \\
JPN & $13.3 \%(11.8 \%)$ & $8.6 \%(7.4 \%)$ & \\
CHN & $9.0 \%(9.8 \%)$ & $5.7 \%(6.2 \%)$ & $13.0 \%(14.3 \%)$ \\
IND & $1.0 \%(1.1 \%)$ & $1.4 \%(1.5 \%)$ & $0.7 \%(0.7 \%)$ \\
ROW & $44.7 \%(48.9 \%)$ & $55.0 \%(59.4 \%)$ & $41.3 \%(45.0 \%)$ \\
\hline Total & $100.0 \%$ & $100.0 \%$ & $100.0 \%$ \\
\hline
\end{tabular}

As can be seen from Table 3, Scenario 1 implies that in the model North America's import shares from Europe and Japan increase from $28.4 \%$ to $31.9 \%$ and from $11.8 \%$ to 13.3\% respectively. On the other hand, North America's import shares from China, India, and ROW, decline from $9.8 \%$ to $9.0 \% \%$, from $1.1 \% \%$ to $1.0 \%$, and from $48.9 \%$ to 44.7\%\% respectively. Scenario 1 assumes similar changes in import shares for Europe and Japan as reported in Table 3.

The real consumption per capita results suggest that relative to the baseline case countries of the North region would suffer from a more intense trade activity with other North countries. Indeed, as can be observed in Figure 4, thanks to the North-North trade strategy which succeeds in making firms and consumers of the North increasing the share of other North countries goods in their import by $5 \%$, real consumption per capita will

\footnotetext{
${ }^{11}$ Benchmark values are in brackets. Benchmark based on the GTAP 6 database (Dimaranan, B. and R. McDougall, 2005).
} 
decline in the North region, whereas consumption per capita will increase in the South region. Figure 4 shows that consumption per capita in Europe is reduced by almost $2 \%$, in Japan by almost $1 \%$ and in North-America by more than $0.5 \%$. On the contrary, real consumption per capita in China, India and Row increases for the entire period 2020 to 2060, albeit modestly. The end result is that from the point of view of the North, diversification with other North countries would not alleviate the pressures of population ageing.

Figure 4. Effect of the trade shock on real consumption per capita, percentage change relative to baseline. North-North diversification.

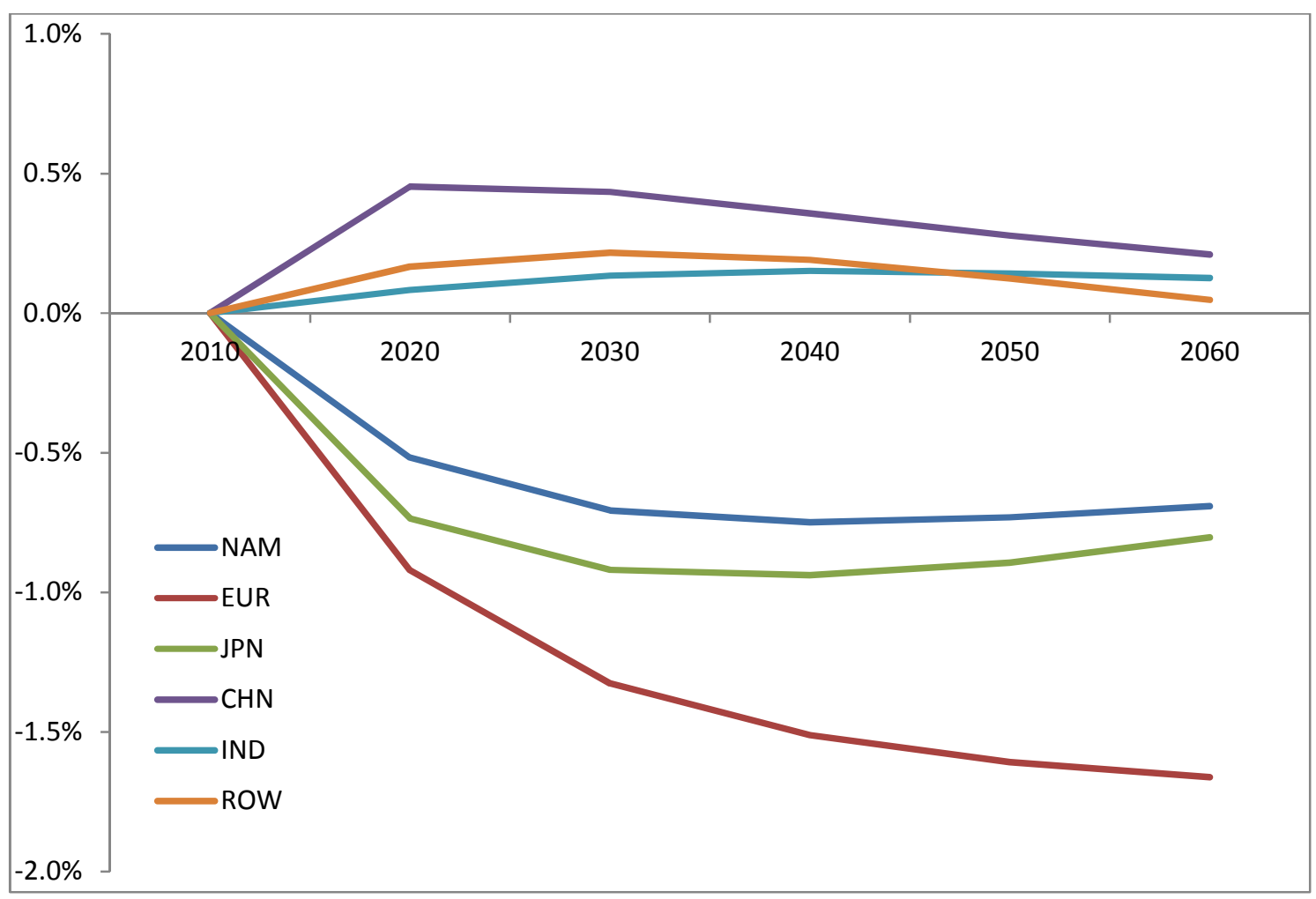


Scenario 2 is the opposite of Scenario 1. This time regions of the North succeed in reducing their import shares from North countries and in increasing simultaneously their import shares from the South region. More precisely, as reported in Table 4, North America's import shares from Europe and Japan decline from $28.4 \%$ to $25.0 \%$ and from $11.8 \%$ to $10.3 \%$ respectively. On the other hand, North America's import shares from China, India, and Row, increase from $9.8 \%$ to $10.7 \%$, from $1.1 \%$ to $1.2 \%$, and from $48.9 \%$ to $52.8 \%$ respectively. Scenario 2 assumes similar changes in import shares for Europe and Japan as reported in Table 4.

Table 4. Benchmark and Counterfactual Regions' Import shares ${ }^{12}$

\begin{tabular}{lccc}
\hline & NAM & EUR & JPN \\
\hline NAM & & $21.7 \%(25.5 \%)$ & $17.5 \%(20.0 \%)$ \\
EUR & $25.0 \%(28.4 \%)$ & & $17.4 \%(20.1 \%)$ \\
JPN & $10.3 \%(11.8 \%)$ & $6.3 \%(7.4 \%)$ & \\
CHN & $10.7 \%(9.8 \%)$ & $6.7 \%(6.2 \%)$ & $15.4 \%(14.3 \%)$ \\
IND & $1.2 \%(1.1 \%)$ & $1.6 \%(1.5 \%)$ & $0.8 \%(0.7 \%)$ \\
ROW & $52.8 \%(48.9 \%)$ & $63.7 \%(59.4 \%)$ & $48.9 \%(45.0 \%)$ \\
\hline Total & $100.0 \%$ & $100.0 \%$ & $100.0 \%$ \\
\hline
\end{tabular}

Simulation results presented on Figure 4 indicate that real consumption per capita in the North improves significantly if North firms and consumers were increasing the share of South goods in their import by $5 \%$. This means that this trade diversification scheme would offset partially the negative impact of ageing by propping-up the real consumption per capita. In fact, between 2010 and 2050, real consumption per capita would increase for North America by over $0.5 \%$ relative to the baseline case. For Europe

\footnotetext{
${ }^{12}$ Benchmark values are in brackets
} 
and Japan the percentage increases are even better, that is close to $1 \%$ for Japan and over $1 \%$ for Europe. All countries of the North would thus benefit from a diversification scheme with the South. Figure 4 and Figure 5 together show that diversifying to other North countries instead of the South would cost Europe, for example, roughly 3\% of real consumption by 2060 .

Figure 5. Effect of the trade shock on real consumption per capita, percentage change relative to baseline. North-South diversification.

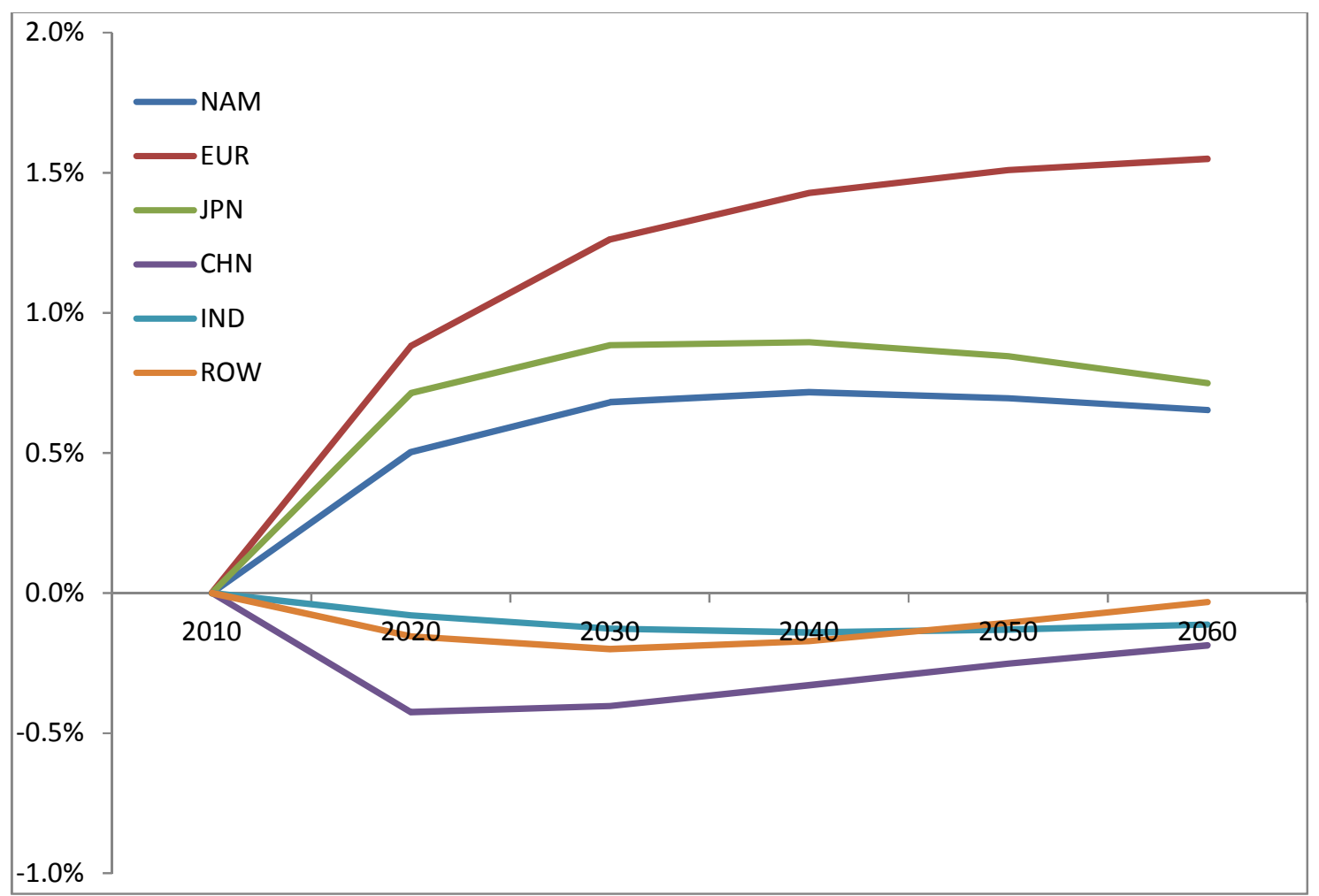




\section{Conclusion}

In this paper, we first made the case that given quite asymmetric population ageing processes between different regions of the world, trade policy can play a role as the upcoming demographic trends may alter significantly the terms of trade. Second, by extending a six-region overlapping generation computable general equilibrium model, we show empirically that various trade diversification schemes have an impact on the extent to which population ageing has an impact on welfare, at least in the North region. In particular, we show that in the context of an ageing population, the North has an interest to expand trade with the South. For instance, the choice of diversifying trade to the North (North-America and Japan) instead of to the South (China, India, and ROW) would cost Europeans roughly $3 \%$ of real consumption by 2050 . At time of hardship, this is quite a significant number.

For future research, a few caveats are in order. First, much related to the tactical issue of how to diversify trade away, we need to be very explicit about what our modelling exercise does and does not do. In this paper, our focus is on the welfare impact of an exogenous change in trade shares and not on the mechanism that might lead to a change in these shares. However, the size, composition, and direction of trade flows result from the decisions of millions of private producers and consumers. These decisions may be influenced by government policy, but large and rapid shift of trade shares might require draconian policy measures. We stress here the importance of supplementing our analysis by studies of policies and institutions that might cause endogenous changes in trade shares, whether multilateral or bilateral trade negotiations, or less formal trade missions. 
Second, there is a related but more subtle issue as to whether we should even consider changing exogenously the benchmark shares of the model. Indeed, those shares are presumably already optimally chosen based on the exogenous variables and parameters in the model and if we change those shares we change the utility function parameters so that we cannot make meaningful welfare comparison. However, initial shares might not be optimal at all (i.e., the economy is not necessarily at a "tangency point"). Existing trade shares reflect all sort of distortions in the economy and social capital (trust, networks) or lack thereof may still prevent countries from establishing deep economic ties with potential trade partners, which is another reason why building international social capital by establishing closer "non-economic" relationships with these countries is so relevant, even prior to developing further trade.

Third, the reliance of our model on the Armington (1969) trade structure which assumes imperfect substitution between goods of different geographical origins, so that the law of one price does not hold in the form given by the Heckscher-Ohlin $(\mathrm{H}-\mathrm{O})$ model. This assumption, typically used in large scale computable models to generate the observed intra-sectoral trade flows between countries, implies that each country has market power and faces a downward-sloping (foreign) demand curve for its product (i.e., its price elasticity is not infinite) ${ }^{13}$ Compared to the $\mathrm{H}-\mathrm{O}$ model, where small shocks can cause production of goods in a country to appear or disappear through comparative advantage adjustment, here quantity adjustment by producers to diverse shocks is somewhat muted by the lack of direct competition between regional producers, while

\footnotetext{
${ }^{13}$ See Lloyd and Zhang (2006) and Zhang (2006) for papers on the effects of the Armington assumption.
} 
terms of trade effects are greater as larger price changes are necessary to clear markets. ${ }^{14}$ Multi-sectoral analyses are however needed, where the Armington assumption could be relaxed depending on the nature of the goods (i.e., differentiated manufactured goods versus homogenous primary goods that would follow the law of one price).

Finally, if the North countries might benefit from North-South trade diversification, the South countries might also want to consider the alternative of SouthSouth trade diversification which would neutralize the terms of trade deterioration that the South may experience if it increases its trade with the North. South countries might theoretically benefit from the net foreign capital flows resulting from the saving of prime savers (in expectation of retirement) in the North, which can finance capital formation and develop further growth in the South. How much of this extra growth may lead to stronger terms of trade deterioration, partly offsetting South's well-being, remains to be analysed in details. However, recent declines in the terms of trade due to growth have been observed by Acemoglu and Ventura (2002) and others.

\footnotetext{
${ }^{14}$ In a sense this assumption also puts us in the ideal position to simulate effects tending towards "enriching decay"/ "immizerising growth" and this is further reinforced by the assumption that each country in our model produces only one good so that variation in population growth will always affect (i.e., be biased toward) the production of the only good we export.
} 


\section{References}

Armington, P.S. (1969), “A Theory of Demand for Products Distinguished by Place of Production”, IMF Staff Papers, vol. 16, 159-76.

Börsch-Supan, A., A. Ludwig and J. Winter (2006), “Aging, Pension Reform and Capital Flows: A Multi-Country Simulation Model”, Economica, vol. 73, 625-58.

Carey, D., and J. Rabesona (2002), "Tax Ratios on Labour and Capital Income and on Consumption”, OECD Economic Studies No. 35.

Dimaranan, B., E. Ianchovichina, and W. Martin (2007), "Competing with Giants. Who Wins, Who Loses?", in Winters, A. and S. Yusuf (2007), (Editors), Dancing with Giants. China, India and the Global Economy, World Bank, Washington, and the Institute of Policy Studies, Singapour.

Dimaranan, B., and R. McDougall (2005), (Editors), Global Trade, Assistance, and Production: The GTAP-6 Data Base, Center for Global Trade Analysis, Purdue University, West Lafayette, Indiana.

Fehr, H., S. Jokisch and L. Kotlikoff (2005), "Will China Eat our Lunch or Take us out to Dinner? Simulating the Transition Paths of the U.S., EU, Japan and China", NBER Working Paper No. 11668.

Fougère, M., S. Harvey, J. Mercenier, and M. Mérette (2009), "Population Ageing, Time Allocation and Human Capital: A General Equilibrium Analysis for Canada", Economic Modelling, vol. 26(1), 690-711.

Laursen, S., and L.A. Metzler (1950), "Flexible Exchange Rates and the Theory of Employment", The Review of Economics and Statistics, vol. 32, 281-99. 
Lloyd P.J., and X.G. Zhang (2006), “The Armington Model”, Staff Working Paper, Productivity Commission, Melbourne.

Mérette, M. and P. Georges (2010), "Demographic Changes and the Gains from Globalisation: An Analysis of Ageing, Capital Flows, and International Trade", Global Economy Journal, 10, (3), Article 3.

Obstfeld, M. (1982), “Aggregate Spending and The Terms of Trade: Is There a LaursenMetzler Effect?", Quarterly Journal of Economics, vol. 97(2), 251-70.

OECD (2005), "Pensions at a Glance: Public Policies across OECD Countries", 2005 Edition, http://www.oecd.org/els/social/aging/PAG.

Shirotori, M. and A.C. Molina (2009), "South-South Trade: The Reality Check”,United Nations Conference on Trade and Development, Geneva, United Nations Publications,

United Nations Population Division (2011), World Population Prospects: The 2010 Revision, http://esa.un.org.unpp.

Winters, A., and S. Yusuf, (2007), (Editors), Dancing with Giants. China, India and the Global Economy, World Bank, Washington, and the Institute of Policy Studies, Singapour.

World Trade Organizations (2012), International Trade Statistics 2012, 274 pages.

Zhang X.G. (2006), “Armington Elasticities and Terms of Trade Effects in Global CGE models", Staff Working Paper, Productivity Commission, Melbourne. 


\section{Appendix: Equations, variables and parameters, and calibration}
A.1 Production sector
(1) $Q_{j, t}=A_{j, t}\left(\operatorname{Kdem}_{j, t}\right)^{\alpha_{j}}\left(\operatorname{Ldem}_{j, t}\right)^{1-\alpha_{j}}, 0<\alpha_{j}<1, \quad j \in J=\{\mathrm{CAN}, \mathrm{USA}, \ldots\}$
(2) $\quad \operatorname{Re} n t_{j, t} / P Q_{j, t}=\alpha_{j} A_{j, t}\left(\operatorname{Kdem}_{j, t} / \operatorname{Ldem}_{j, t}\right)^{\alpha_{j}-1}$
(3) $\quad W_{\operatorname{Ldem}} / P Q_{j, t}=\left(1-\alpha_{j}\right) A_{j, t}\left(\operatorname{Kdem}_{j, t} / \operatorname{Ldem}_{j, t}\right)^{\alpha_{j}}$

A.2 Household behaviour and pension plans

(4) $U_{j, t}=\left(1 /\left(1-\gamma_{j}\right)\right) \sum_{k=0}^{6}\left\{\left(1 /\left(1+\psi_{j}\right)\right)^{k+1}\left(\left(\operatorname{Con}_{j, t+k, g+k}\right)^{1-\gamma_{j}}\right)\right\}, \quad 0<\gamma_{j}<1$

$$
\begin{aligned}
& \underbrace{\text { Lend }_{j, t+1, g,+1}-\text { Lend }_{j, t, g g}}_{\text {Asset Accumulation (during period } t)}=\underbrace{\left(1-\tau_{j, t}^{L}-C T R_{j, t}\right) Y_{j, t, g g}^{L}}_{\text {Net Labour Income }}+\underbrace{\left(1-\tau_{j, t}^{K}\right) r e t_{j, t} \text { Lend }_{j, t, g g}}_{\text {Net Capital Income }} \\
& +\underbrace{\text { Pens }}_{\text {Pension Benefit }} \underbrace{}_{j, t, g g}-\left(1+\tau_{j, t}^{C}\right) \underbrace{P C \text { Con }_{j, t} \text { Con }_{j, t, g g}}_{\text {Net Consumption Spending }}, \\
& \quad g g \in G G=\{g, g+1, \ldots, g+6\}=\{g+k ; k=0, \ldots, 6\}
\end{aligned}
$$

(6) $\quad Y_{j, t, g g}^{L}=W L \operatorname{dem}_{j, t} E P_{j, g g} L S_{j, g g}$

(7) $E P_{j, g g}=\omega+(\xi)(g g)-(\phi)(g g)^{2}, \quad \omega, \xi, \phi \geq 0$

(8) $\operatorname{Con}_{j, t+1, g g+1} / \operatorname{Con}_{j, t, g g}=$

$$
\left[\left(\left(1+\left(1-\tau_{j, t+1}^{K}\right) \operatorname{ret}_{j, t+1}\right) /\left(1+\psi_{j}\right)\right) \times\left(\operatorname{PCon}_{j, t}\left(1+\tau_{j, t}^{C}\right) / \operatorname{PCon}_{j, t+1}\left(1+\tau_{j, t+1}^{C}\right)\right)\right]_{\gamma_{j}}^{\frac{1}{1}}
$$

(9) $\operatorname{ConI}_{i, j, t, g g}=A L C I_{i, j}{ }^{\operatorname{Sig}_{j}}\left(\mathrm{PCon}_{j, t} / P Q_{i, t}\right)^{\operatorname{SigC}_{j}} \mathrm{Con}_{j, t, g g}$,

$$
i \in J=\{\mathrm{CAN}, \mathrm{USA}, \ldots\}
$$

(10) $\quad \operatorname{PCon}_{j, t}=\left[\sum_{i} A L C I_{i, j} \operatorname{SigC}_{j}\left(P Q_{i, t}\right)^{\left(1-S i g C_{j}\right)}\right]^{\frac{1}{1-S i g C_{j}}}$

(11) Pens $_{j, t+5, g+5}=$ Pens $_{j, t+6, g+6}=$ PensR $_{j, t, g}\left((1 / 5) \sum_{k=0}^{4} Y_{j, t+k, g+k}^{L}\right)$

(12) $\sum_{g m}$ Pop $_{j, t, g m}$ Pens $_{j, t, g m}=C T R_{j, t} \sum_{g j} \operatorname{Pop}_{j, t, g j} Y_{j, t, g j}^{L}$,

$$
g j \in G J=\{g+k ; k=0, \ldots, 4)\}, \quad g m \in G M=\{g+5, g+6\}
$$

A.3 Investment and asset returns

(13) $\quad \operatorname{InvI}_{i, j, t}=A L I I_{i, j}{ }^{\operatorname{Sig} I_{j}}\left(P \operatorname{Inv} v_{j, t} / P Q_{i, t}\right)^{\operatorname{SigI}_{j}} \operatorname{Inv} v_{j, t}$

(14) $\quad \operatorname{PInv}_{j, t}=\left[\sum_{i} A L I I_{i, j}{ }^{\operatorname{SigI}_{j}}\left(P Q_{i, t}\right)^{\left(1-\operatorname{SigI}_{j}\right)}\right]^{\frac{1}{1-\operatorname{SigI}_{j}}}$ 
(15) Kstock $_{j, t+1}=\operatorname{Inv}_{j, t}+\left(1-\delta_{j}\right)$ Kstock $_{j, t}$

(16) ret $_{j, t}=$

$$
\underbrace{\operatorname{Re} n t_{j, t} / P \operatorname{In} v_{j, t-1}}_{\begin{array}{c}
\text { Rental Price of Capital } \\
\text { (in terms of the investment good) }
\end{array}}+\underbrace{\left(P \operatorname{In} v_{j, t}-P \operatorname{In} v_{j, t-1}\right) / P \operatorname{Inv} v_{j, t-1}}_{\text {Expected Capital Gains }}-\underbrace{\delta_{j} P \operatorname{Inv} v_{j, t} / P \operatorname{In} v_{j, t-1}}_{\text {Depreciation Cost }}
$$

$$
\underbrace{r i_{j, t-1}}_{\text {Promised Rate of Return }}+\underbrace{\left(P G o v_{j, t}-P G o v_{j, t-1}\right) / P G o v_{j, t-1}}_{\text {Expected Capital Gains on Bonds }}
$$

(18) $r e t_{j, t}=r i_{j, t-1}+\left(\right.$ PGov $_{j, t}-$ PGov $\left._{j, t-1}\right) /$ PGov $_{j, t-1}$

(19) $r$ int $_{t}=r i_{j, t-1}+\left(\right.$ PGov $_{j, t}-$ PGov $\left._{j, t-1}\right) /$ PGov $_{j, t-1}, \forall j$

(20) $\quad r$ int $_{t}=\operatorname{ret}_{j, t}, \forall j$

\section{A.4 Government sector}

(21) $\quad$ PGov $_{j, t}$ Bond $_{j, t+1}-$ PGov $_{j, t-1}$ Bond $_{j, t}=$

PGov $_{j, t}$ Gov $_{j, t}+\left(\right.$ ri $_{j, t-1}+\left(\right.$ PGov $_{j, t}-$ PGov $\left._{j, t-1}\right) /$ PGov $\left._{j, t-1}\right)$ PGov $_{j, t-1}$ Bond $_{j, t}$

$-\sum_{g g} P O P_{j, t, g g}\left\{\tau_{j, t}^{L}\left(Y_{j, t, g g}^{L}\right)+\tau_{j, t}^{C}\left(\right.\right.$ Pcon $_{j, t}$ Con $\left._{j, t, g g}\right)+\tau_{j, t}^{K}\left(\right.$ ret $_{j, t}$ Lend $\left.\left._{j, t, g g}\right)\right\}$

(22) $\operatorname{GovI}_{i, j, t}=A L G I_{i, j}{ }^{\operatorname{Sig} G_{j}}\left(P G o v_{j, t} / P Q_{i, t}\right)^{S i g G_{j}} \operatorname{Gov}_{j, t}$

$$
\text { PGov }_{j, t}=\left[\sum_{i} A L G I_{i, j} \operatorname{SigG}_{j}\left(P Q_{i, t}\right)^{\left(1-S i g G_{j}\right)}\right]^{\frac{1}{1-S i g G_{j}}}
$$

A.5 Market and aggregation conditions

$$
Q_{j, t}=\sum_{i} E_{j, i, t}=\sum_{i}\left[\left(\sum_{g g} \operatorname{Pop}_{i, t, g g} \operatorname{ConI}_{j, i, t, g g}\right)+\operatorname{InvI}_{j, i, t}+\operatorname{GovI}_{j, i, t}\right]
$$

(26) Kdem $_{j, t}=$ Kstock $_{j, t}$

(27) $\sum_{i} \sum_{g g}$ Pop $_{i, t+1, g g}$ Lend $_{i, t+1, g g}=\sum_{i}$ PGov $_{i, t}$ Bond $_{i, t+1}+\sum_{i}$ PInv $_{i, t}$ Kstock $_{i, t+1}$

$$
C A_{j, t}=\underbrace{\left(\sum_{g g} \text { Pop }_{j, t+1, g g} \text { Lend }_{j, t+1, g g}-\sum_{g g} \text { Pop }_{j, t, g g} \text { Lend }_{j, t, g g}\right)}_{\text {Private Saving }}-
$$

$\underbrace{\left(\text { PGov }_{j, t} \text { Bond }_{j, t+1}-\text { PGov }_{j, t-1} \text { Bond }_{j, t}\right)}-\underbrace{\left(\text { PInv }_{j, t} \text { Kstock }_{j, t+1}-\text { PInv }_{j, t-1} K_{\text {stock }}\right)}$ 


$$
\begin{aligned}
& C A_{j, t}=\underbrace{\left(\sum_{i, i \neq j} P Q_{j, t} E_{j, i, t}-P Q_{i, j} E_{i, j, t}\right)}_{\text {Trade Balance }}+ \\
& \operatorname{rint} t(\underbrace{\sum_{g g} P o p_{j, t, g g} \text { Lend }_{j, t, g g}}_{\text {Wealth of Country } j}-\underbrace{\left(P G o v_{j, t-1} \text { Bond }_{j, t}+P I n v_{j, t-1} \text { Kstock }_{j, t}\right)}_{\text {Assets issed by Country } j})
\end{aligned}
$$

\begin{tabular}{|c|c|}
\hline Variables & Description \\
\hline$Q_{j, t}$ & region- $j$ output \\
\hline$P Q_{j, t}$ & region- $j$ output price (producer price index) \\
\hline $\mathrm{Kdem}_{j, t}$ & physical capital \\
\hline $\operatorname{Ldem}_{j, t}$ & effective units of labour \\
\hline $\operatorname{Re}_{j, t}$ & rental rate of capital \\
\hline WLdem $_{j, t}$ & wages for effective units of labour \\
\hline Con $_{j, t, g g}$ & consumption demand of household of generation $g g$ at time $t$ \\
\hline$C_{j, t}$ & $=\sum_{g g} \operatorname{Con}_{j, t, g g}=$ aggregate consumption in region $j$ at time $t$ \\
\hline ConI $_{i, j, t, g g}$ & household-gg of region-j's consumption demand for a region- $i$ good \\
\hline PCon $_{j, t}$ & composite consumption price index \\
\hline Lend $d_{j, t, g g}$ & stock of wealth accumulated by household- $g g$ at the end of period $t-1$ \\
\hline Kstock $_{j, t}$ & region- $j$ capital stock \\
\hline $\operatorname{In} v_{j, t}$ & investment in region- $j$ \\
\hline $\operatorname{InvI_{i,j,t}}$ & region-j's investment demand for a region- $i$ (investment) good \\
\hline$P \operatorname{Inv} v_{j, t}$ & composite investment good price index \\
\hline$r e t_{j, t}$ & $\begin{array}{l}\text { expected rate of return on physical capital purchased at end of } t-1 \text { and } \\
\text { rented throughout } t\end{array}$ \\
\hline$r i_{j, t-1}$ & $\begin{array}{l}\text { promised coupon rate of interest on country- } j \text { government bonds issued at } \\
\text { end of } t-1\end{array}$ \\
\hline rint $_{t}$ & world interest rate, expected as of the end of period $t-1$ for period $t$ \\
\hline Gov $_{j, t}$ & region- $j$ real public expenditures \\
\hline GovI $_{i, j, t}$ & real public expenditures of government $-j$ on goods from region $i$ \\
\hline$P G o v_{j, t}$ & $\begin{array}{l}\text { composite government spending price index (price of bonds issued by } \\
\text { region- } j \text { government) }\end{array}$ \\
\hline$E_{j, i, t}$ & real bilateral export of country $j$ to county $i$ \\
\hline$C A_{j, t}$ & country- $j$ current account \\
\hline Pens $_{j, t, g m}$ & pension benefit to retired generations $(\mathrm{gm})$ \\
\hline$Y_{j, t, g g}^{L}$ & labour income of household- $g g$ \\
\hline$L S_{j, g g}$ & supply of physical units of labour by household- $g g$ (exogenous) \\
\hline$E P_{j, g g}$ & household age-dependent productivity (earnings) profile \\
\hline Pop & population size of working-age cohorts $g i$ \\
\hline
\end{tabular}

Table A1. Model variables and parameters 


\begin{tabular}{|l|l|}
\hline Pop $_{j, t, g m}$ & population size of retired cohorts $g m$ \\
\hline Parameters & Description \\
\hline$A_{j, t}$ & scaling factor of Cobb-Douglas production function (TFP) \\
\hline$\alpha_{j}$ & share of physical capital in Cobb-Douglas production function \\
\hline$\psi_{j}$ & pure rate of time preference \\
\hline$\gamma_{j}$ & inverse of the constant inter-temporal elasticity of substitution \\
\hline$I_{j, t}$ & effective tax rate on labour income (endogenous) \\
\hline$I_{j, t}$ & effective tax rate on capital income \\
\hline$I_{j, t}$ & consumption tax rate \\
\hline$C T R_{j, t}$ & contribution to the public pension system (endogenous) \\
\hline$P e n s R_{j, t, g g}$ & pension replacement rate (exogenous) \\
\hline$\delta_{j}$ & depreciation rate of capital \\
\hline$A L C I_{i, j}$ & country- $i$ share of country- $j$ consumption-good demand \\
\hline$A L I I_{i, j}$ & country- $i$ share of country- $j$ investment-good demand \\
\hline$A L G I_{i, j}$ & country- $i$ share of country- government consumption demand \\
\hline$S i g C_{j}$ & Armington substitution elasticities in consumption goods \\
\hline$S i g I_{j}$ & Armington substitution elasticities in investment goods \\
\hline$S i g G_{j}$ & Armington substitution elasticities in government consumption \\
\hline$N N_{j, t}$ & country-specific per-capita number of children \\
\hline$n m_{j, t, g g}$ & net migration ratio \\
\hline$s_{j, t, g g}$ & conditional survival rate \\
\hline
\end{tabular}

